九州大学学術情報リポジトリ

Kyushu University Institutional Repository

\title{
Relationship between Gas Content and Hematocrit Value in Yellowtail Blood
}

Yamamoto, Kenichi

Department of Fisheries, Faculty of Agriculture, Kyushu University

Itazawa, Yasuo

Department of Fisheries, Faculty of Agriculture, Kyushu University

Kobayashi, Hiroshi

Shimonoseki University of Fisheries

https://doi.org/10.5109/23736

出版情報: 九州大学大学院農学研究院紀要. 26 (1)，pp.31-37，1981-10. Kyushu University バージョン：

権利関係 : 
J.Fac. Agr., Kyushu Univ., 26(1), 51-37 (1981)

\title{
Relationship between Gas Content and Hematocrit Value in Yellowtail Blood
}

\author{
Ken-ichi Yamamoto* and Yasuo Itazawa \\ Department of Fisheries, Faculty of Agriculture, \\ Kyushu University 46-04, Fukuoka 812 \\ Hiroshi Kobayashi \\ Shimonoseki University of Fisheries, Nagata-honmachi, \\ Yoshimi, Shimonoseki 759-65
}

(Received May 28, 1981)

\begin{abstract}
The hematocrit value of fish blood is known to easily vary with physiological conditions of the fish. The relationships between gas contents and hematocrit value were examined in the yellowtail Seriola quinqueradiata to know respiratory abilities of the fish at various hematocrit conditions. The oxygen capacity, oxygen content and oxygen saturation in the arterial blood, and the oxygen content and oxygen saturation in the mixed venous blood increased with hematocrit elevation. The regression equations of these relationships were obtained. The oxygen utilization at the tissues markedly elevated in fish of low hematocrit values. This phenomenon is considered to be an adjustment to maintain the oxygen supply to the tissues at fairly good levels under lowered oxygen transport of the arterial blood caused by low hematocrit values. The carbon dioxide contents both in the arterial blood and in the mixed venous blood were fairly constant over a wide range of hematocrit value.
\end{abstract}

\section{INTRODUCTION}

The hematocrit value of fish blood is known to vary with physiological conditions of the fish. Increase in hematocrit value has been observed in the rainbow trout (Black et al., 1959, 1962, 1966) and the yellowtail (Yamamoto et al.. 1980) during exercise, and in the striped mullet at high temperatures (Cameron, 1970). Decrease in hematocrit value was also observed at high temperatures in the pinfish (Cameron, 1970). Decrease in hematocrit value is usually accompanied with decrease in hemoglobin concentration or anemia which is observed at bleeding and diseases caused by toxins, infectious bacteria, parasites and poor nutrition (Kawatsu, 1978).

Relationship between gas content and hematocrit value is considered to be worthwhile to study in order to know respiratory abilities of the fish at various hematocrit conditions. This paper presents data on relationship between gas content and hematocrit value in the yellowtail which is an imp\&-

* Present address: Ono Limnological Station, Shimonoseki University of Fisheries, Onö, Ube 754-13. 
tant species in sea fisheries and fish farming in Japan.

\section{MATERIALS AND METHODS}

The experiments were carried out on 24 yellowtail Seriola quinqueradiata of 715-1246 (9291140) $\mathrm{g}$ in weight and 394-482 (441 \pm 29$) \mathrm{mm}$ in total length. The fish were raised at a marine farm of Kuroi Fisheries Co-operative in Yamaguchi Prefecture, and transported to Shimonoseki University of Fisheries. They had been kept for one or two days before experimentation in air-saturated water.

A fish was cannulated to either the dorsal aorta or the bulbus arteriosus with a polyethylene tubing of $1.0 \mathrm{~mm}$ outside diameter, under branchial irrigation with $1: 50,000$ quinaldine, by the method described in the previous paper (Yamamoto et al., 1981). The cannulated fish was placed in a net cage of 50 $\mathrm{cm} \times 50 \mathrm{~cm} \times 50 \mathrm{~cm}$ set in a tank of $2 \mathrm{~m} \times 1 \mathrm{mx} 0.8 \mathrm{~m}$ (depth of water) gently

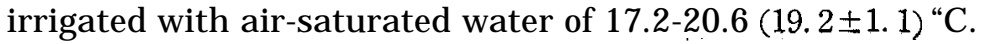

After 18-20 hours from placing fish in the cage, $1.5 \mathrm{ml}$ of the blood was collected from the fish through the cannula by the following procedures. After removing the physiological saline in the cannula (about $0.1 \mathrm{ml}$ ), $0.3 \mathrm{ml}$ of the blood was collected and stored. Then $1.5 \mathrm{ml}$ of the blood was collected in another syringe and offered to gas analysis. After collection of the $1.5 \mathrm{ml}$ of blood, the stored blood $(0.3 \mathrm{ml})$ was returned into the circulating blood through the cannula. And then, the cannula was filled with fresh saline. Yellowtail of this size is considered to contain the blood of about $50 \mathrm{ml}$, estimated based on our previous work (Yamamoto et al., 1980).

The oxygen capacity of the blood was determined, using $0.5 \mathrm{ml}$ of the blood sample, by measuring the oxygen content after shaking the blood with air for ten minutes. "Oxygen capacity" in the present paper means the oxygen content of the well-oxygenated blood including the dissolved oxygen. The contents of oxygen and carbon dioxide in the blood were determined with 0.5 $\mathrm{ml}$ of sample by the manometric method of Van Slyke and Neil1 (1924). The hematocrit value of the blood was determined by centrifugation, of sample in a capillary tube at $11,000 \mathrm{rpm}$ for five minutes.

Blood with hematocrit values in the normal range $(29.3 \pm 2.9 \%$ for the arterial blood and 29.8t3.4 \% for the mixed venous blood) was obtained after 18-20 hours of recovery from the cannulating operation. This duration, 18-20 hours, is considered to be long enough for recovering "resting condition* judging from the following facts, After severe exercise, yellowtail recovered the pre-exercise levels of hematocrit value, hemoglobin concentration and water content of the blood within one hour, and those of weight and hemoglobin content of the spleen within five hours (Yamamoto et al., 1980). And after operation for an abdominal window which gives severer effect on fish than cannulating operation, yellowtail showed almost same level of oxygen consumption at $4-6$ hours after the operation $(1.935 \pm 0.420 \mathrm{ml} / \mathrm{min} / \mathrm{kg}, \mathrm{N}=20)$ as that at 18 hours after cannulating operation $(1.930 \pm 0.310 \mathrm{ml} / \mathrm{min} / \mathrm{kg}, \mathrm{N}=14$ ) both at $20-21^{\circ} \mathrm{C}$ (Yamamoto, Itazawa and Kobayashi, unpublished). Blood with 
high hematocrit values was obtained from fish kept under anesthesia by a direct puncture to the bulbus arteriosus. Blood with low hematocrit values was obtained from anemic fish kept unfed for 10-14 days after taking $1.5 \mathrm{ml}$ of the blood.

\section{RESULTS}

The oxygen capacity of the blood $\left(\mathrm{O}_{2}\right.$ cap., $\left.\mathrm{ml} / \mathrm{dl}\right)$, the oxygen content in the arterial blood $\left(\mathrm{C}_{\mathrm{a}, \mathrm{O}_{2}}, \mathrm{ml} / \mathrm{dl}\right)$, and the oxygen content of the mixed venous blood $\left(\mathrm{C}_{\overline{\mathrm{v}}, \mathrm{o}_{2}}, \mathrm{ml} / \mathrm{dl}\right)$ increased with elevation of the hematocrit value $(\mathrm{Ht}, \%)$, as shown in Fig. 1. The relationships are expressed as the following equalions calculated based on the least square method:

$$
\begin{aligned}
& \mathrm{O}_{2} \text { cap. }=0.436 \mathrm{Ht}+0.683(\mathrm{r}=0.955) \\
& \mathrm{C}_{\mathrm{a} .0_{2}}=0.363 \mathrm{Ht}+\mathrm{O} .797(\mathrm{r}=0.907) \\
& \mathrm{C}_{\overline{\mathrm{v}}, \mathrm{o}_{2}}=0.373 \mathrm{Ht}-2.950(\mathrm{r}=\mathrm{O} .962)
\end{aligned}
$$

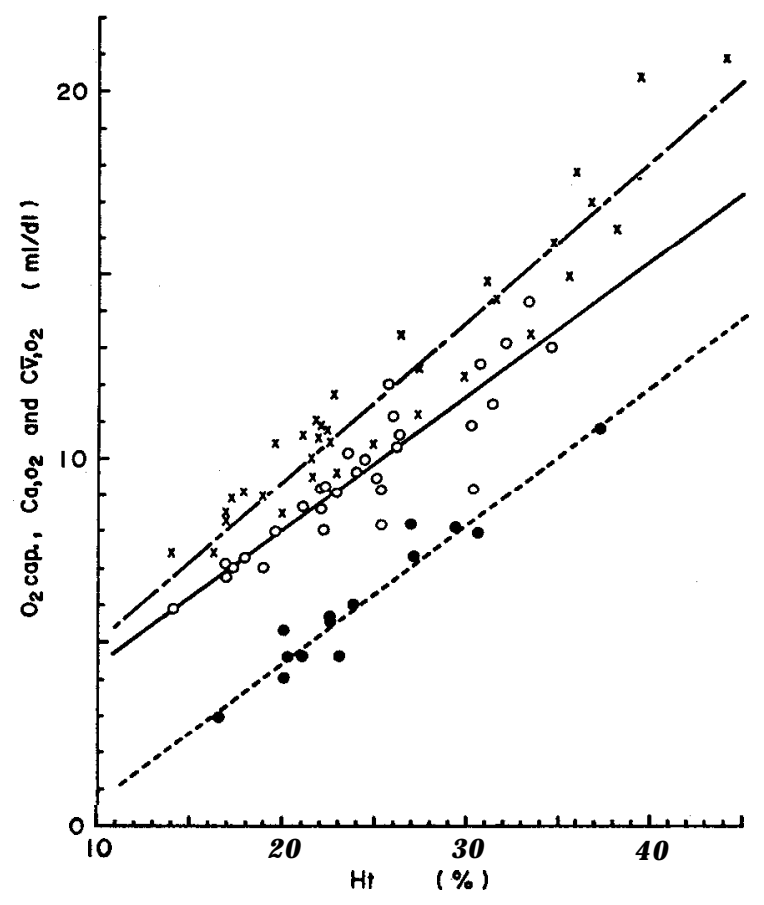

Fig. 1. Relationships of the oxygen capacity of the yellowtail blood $\left(\mathrm{O}_{2}\right.$ cap., shown by crosses with dots and lines), the oxygen content of the arterial blood $\left(\mathrm{C}_{\mathrm{a}, \mathrm{O}_{2}}\right.$, open circles with a solid line $)$ and that of the mixed venqus blood $\left(C_{\overline{\mathbf{v}}} \mathbf{o}_{2}\right.$, solid circles with a dotted line) to the hematocrit value $(\mathrm{Ht})$.

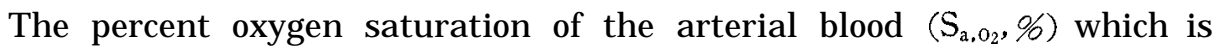
$\mathrm{C}_{\mathrm{a}, \mathrm{O}_{2}}$ divided by $\mathrm{O}_{2}$ cap., decreased very slightly with hematocrit elevation, 


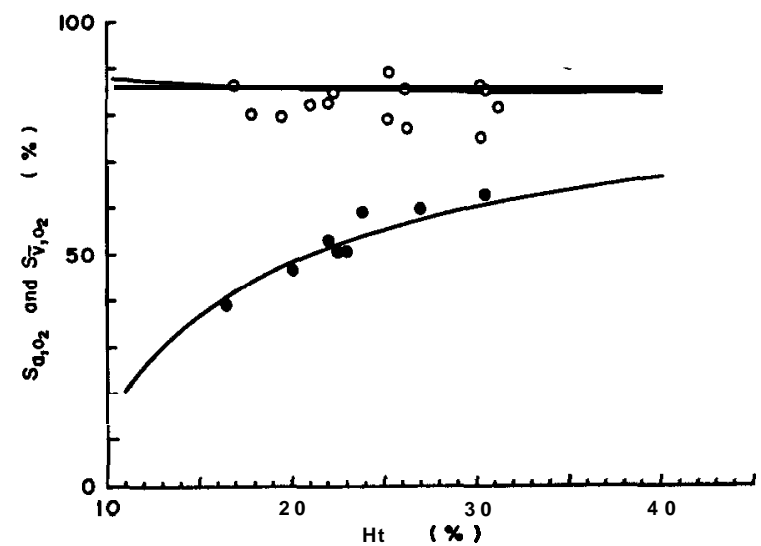

Fig. 2. Relationships of the oxygen saturation of the arterial blood $\left(S_{\mathbf{a}, \mathbf{O}_{2}}\right.$, shown by open circles) and that of the mixed venous blood $\left(\mathrm{S}_{\overrightarrow{\mathrm{v}}, \mathrm{o}_{2}}\right.$, solid circles) to the hematocrit value $(\mathrm{Ht})$. with the curves showing calculated values based on the equations (4) and (5).

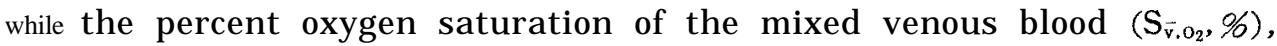
which is $\mathrm{C}_{\overline{\mathrm{v}}, \mathrm{o}_{2}}$ divided by $\mathrm{O}_{2}$ cap., markedly increased with hematocrit elevation, as shown in Fig. 2. The relationships calculated based on the following equations are also shown as curves in Fig. 2.

$$
\begin{aligned}
\mathrm{S}_{\mathrm{a}, \mathrm{o}_{2}} & =100 \times \text { equation }(2) / \text { equation }(1) \\
& =100(0.363 \mathrm{Ht}+0.797) /(0.436 \mathrm{Ht}+0.683) \\
\mathrm{S}_{\bar{v}, o_{2}} & =100 \mathrm{x} \text { equation }(3) / \text { equation }(1) \\
& =100(0.373 \mathrm{Ht}-2.950) /(0.436 \mathrm{Ht}+0.683)
\end{aligned}
$$

The oxygen utilization at the tissues or the coefficient of oxygen extraction from blood (U,\%) markedly decreased with hematocrit elevation, as shown in Fig. 3, and the relationship is expressed by the following equation:

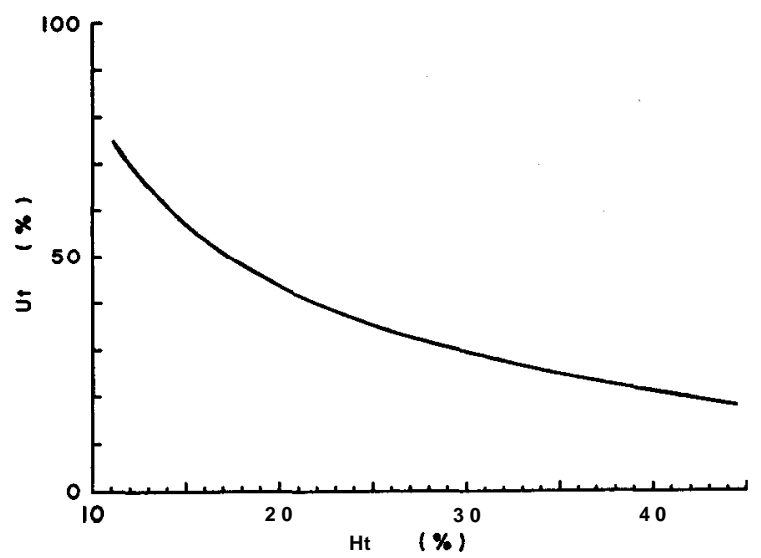

Fig. 3. Relationship between the oxygen utilization at the tissues $\left(U_{t}\right)$ and the hematocrit value $(\mathrm{Ht})$. 


$$
\begin{aligned}
\mathrm{U}_{\mathrm{t}} & =100\left(\mathrm{C}_{\mathrm{a}, \mathrm{o}_{2}}-\mathrm{C}_{\overline{\mathrm{v}}, \mathrm{o}_{2}}\right) / \mathrm{C}_{\mathrm{a}, \mathrm{O}_{2}} \\
& =100(-0.010 \mathrm{Ht}+3.747) /(0.363 \mathrm{Ht}+0.797)
\end{aligned}
$$

The carbon dioxide contents both in the arterial blood $\left(\mathrm{C}_{\mathrm{a}, \mathrm{Co}_{2}}, \mathrm{ml} / \mathrm{dl}\right)$

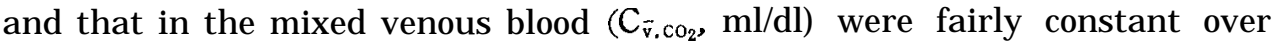
the wide range of hematocrit value from 16 to $37 \%$, as shown in Fig. 4 . The mean value and the standard deviations of $\mathrm{C}_{\mathrm{a}, \mathrm{Co}_{2}}$ and $\mathrm{C}_{\overline{\mathrm{v}}, \mathrm{Co}_{2}}$ were $9.87 \pm 0.79$ $\mathrm{ml} / \mathrm{dl}$ and $12.74 \pm 1.73 \mathrm{ml} / \mathrm{dl}$, respectively.

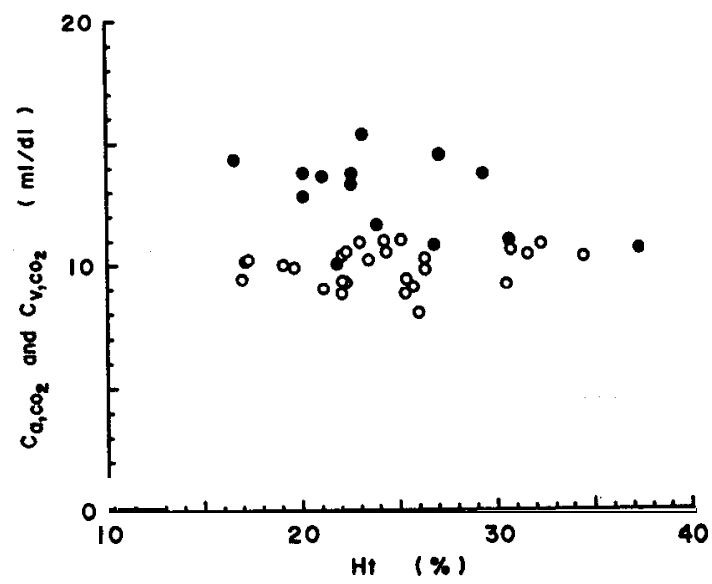

Fig. 4. Relationships of the carbon dioxide content of the arterial blood $\left(\mathrm{C}_{\mathrm{a}, \mathrm{CO}_{2}}\right.$, shown by open circles) and that of the mixed venous blood $\left(\mathrm{C}_{\bar{v}}, \mathrm{CO}_{2}\right.$, solid circles) to the hematocrit value $(\mathrm{Ht})$.

\section{DISCUSSION}

The relationship between the oxygen capacity and the hematocrit value was reported to be $\mathrm{O}_{2}$ cap. $=0.311 \mathrm{Ht}+0.7$ in the rainbow trout (Holeton and Randall, 1967), and $\mathrm{O}_{2}$ cap. $=$ O. $24 \mathrm{Ht+l}$. 69 in the tench (Eddy, 1973). The relationship in the yellowtail, $\mathrm{O}_{2}$ cap. $=0.436 \mathrm{Ht}+\mathrm{O} .683$, shows a large oxygen capacity of the blood of this fish for a unit volume of erythrocytes, and means that the hemoglobin is condensely contained in the erythrocytes.

The difference between the oxygen content in the arterial blood and that in the mixed venous blood is almost constant (about $3.7 \mathrm{ml} / \mathrm{dl}$ ) over the wide range of hematocrit value, as shown by an equation $\mathrm{C}_{\mathrm{a}, \mathrm{o}_{2}}-\mathrm{C}_{\overline{\mathrm{v}}, \mathrm{o}_{2}}=-0.010 \mathrm{Ht}+$ 3.747. The rate of oxygen consumption $\left(\dot{\mathrm{V}}_{\mathrm{O}_{2}}, \mathrm{ml} / \mathrm{min} / \mathrm{kg}\right)$ was reported to be almost constant at various hematocrit values in the rainbow trout (Cameron and Davis, 1970) and the pinfish (Cameron and Wohlschlag, 1969). If it is also true in the yellowtail, the cardiac output $\left(\dot{\mathrm{V}}_{\mathrm{b}}, \mathrm{ml} / \mathrm{min} / \mathrm{kg}\right)$ of this fish is considered to be almost constant at various hematocrit values, estimated from Fick's principle, $\dot{\mathrm{V}}_{\mathrm{b}}=100 \dot{\mathrm{V}}_{\mathrm{o}_{2}} /\left(\mathrm{C}_{\mathrm{a}, 0_{2}}-\mathrm{C}_{\overline{\mathrm{v}}, \mathrm{o}_{2}}\right)$.

The oxygen utilization at the tissues markedly elevated at low hematocrit values as shown in Fig. 3. This phenomenon is considered to be an adjust- 
ment to maintain the oxygen supply to the tissues at fairly good levels under lowered levels of oxygen transport of the arterial blood caused by low hematocrit values. The marked drop of oxygen saturation in the mixed venous blood at low hematocrit values shown in Fig. 2 reflects the increased oxygen utilization at the tissues. The decrease of oxygen saturation in the mixed venous blood is comparable with decrease of oxygen saturation in the venous blood by elevated metabolism owing to elevated temperature (Heath and Hughes, 1973; Watters and Smith, 1973; Kobayashi and Yamamoto, 1977) and exercise (Stevens and Randall, 1967).

\section{REFERENCES}

Black, E. C., W.-G. Chiu, F. D. Forbes and A. Hanslip 1959 Changes in pH, carbonate, and lactate of the blood of yearling Kamloops trout, Salmo gairdneri during and following severe muscular activity. J.Fish. Res. 'Bd. Canada, 16: 391-402

Black, E. C., A. R. Connor, K.-C. Lam and W.-G. Chiu 1962 Changes in glycogen, pyruvate and lactate in rainbow trout Salmo gairdneri during and following muscular activity. J. Fish. Res. Bd. Canada, 19: 409-436

Black, E. C., G. T. Manning and K. Hayashi 1966 Changes in levels of hemoglobin, oxygen. carbon dioxide, pyruvate, and lactate in venous blood of rainbow trout (Salmo gairdneri) during and following severe muscular activity. J. Fish. Res. Bd. Canada, 23: 783-795

Cameron, J. N. 1970 The influence of environmental variables on the hematology of pinfish (Lagodon rhomboides) and striped mullet (Mugil cephalus). Comp. Biochem. Physiol., 32 : $175-192$

Cameron, J. N. and J. C. Davis 1970 Gas exchange in rainbow trout (Salmogairdneri) with varying blood oxygen capacity. J. Fish. Res. Bd. Canada. 27: 1069-1085

Cameron, J. N. and D. E. Wohlschlag 1969 Respiratory response to experimentally induced anemia in the pinfish (Lagodon rhomboides). J. Exp. Biol., 50: 307-317

Eddy, F. B. 1973 Oxygen dissociation curves of the blood of the tench. Tincatinca.J. Exp. Biol.. $58: 281-293$

Heath, A. G. and G. M. Hughes 1973 Cardiovascular and respiratory changes during heat stress in rainbow trout (Salmo gairdneri). J. Exp. Biol., 59: 323-338

Holeton, G. F. and D. J. Randall 1967 The effect of hypoxia upon the partial pressure of gases in the blood and water afferent and efferent to the gills of rainbow trout. J. Exp. Biol., 46: 317-327

Kawatsu, H. 1978 Gyorui no hinketsu-sho. In 'Sakana no Kokyu to Junkan," ed. by Nihon Suisan Gakkai, Koseisha Koseikaku, Tokyo.. pp. 81-95

Kobayashi, H. and K. Yamamoto 1977 Some aspects on oxygen and total carbon dioxide contents in blood of the yellowtail, Seriola quinqueradiata. J. Shimonoseki Univ. Fish., $25: 197-212$

Stevens, E. D. and D. J. Randall 1967 Changes of gas concentrations in blood and water during moderate swimming activity in rainbow trout. J. Exp. Biol., 46: 329-337

Van Slyke, D. D. and J. M. Neill 1924 The determination of gases in blood and other solutions by vacuum extraction and manometric measurement-I. J. Biol.Chem., 61: 523-573

Watters, K. W. and L. S. Smith 1973 Respiratory dynamics of the starry flounder Platichthys stellatus in response to low oxygen and high temperature. Marine Biology, 19 : 133-148 
Yamamoto, K., Y. Itazawa and H. Kobayashi 1980 Supply of erythrocytes into the circulating blood from the spleen of exercised fish. Comp. Biochem. Physiol., 65A: 5-11

Yamamoto, K., Y. Itazawa and H. Kobayashi 1981 Gas exchange in the gills of yellowtail Seriola quinqueradiata under resting and normoxic condition. Bull. Japan. Soc. Sci. Fish., 47: 447-451 